2017, Vol. 03(I) 01-26

\title{
The Audit Expectations Gap and the Role of Audit Education: Evidence from Sri Lanka
}

\author{
J.S. Kumari \\ University of Rajarata, Sri Lanka
}

\author{
A.R. Ajward \\ University of Sri Jayewardenepura, Sri Lanka \\ D.B.P.H. Dissabandara \\ University of Sri Jayewardenepura, Sri Lanka
}

\begin{abstract}
The study examined the status and impact of audit education on the audit expectation gap, as existence of such a gap is noted to be harmful to the accounting and auditing profession. Accordingly, undergraduates of a regional national university in Sri Lanka (in three categories as: undergraduates who had not followed an auditing course, who had followed a basic auditing course, and who had followed an advanced auditing course) and professional auditors were selected and a questionnaire survey that included statements on the duties of the auditors was administered. The results of the independent sample t-test indicate the existence of an audit expectation gap in the Sri Lankan context; and that audit education had an effect in reducing such a gap. However, further analysis indicated that only an advanced auditing course had resulted in minimizing such expectation gap (particularly in reducing the unreasonable expectation gap) compared to who had followed a basic auditing course. These findings are expected to have significant educational policy implications.
\end{abstract}

\section{Corresponding Author:}

Ms. J.S. Kumari is a Senior Lecturer at the Department of Accountancy and Finance, University of Rajarata, Mihintale, Sri Lanka. E-mail: skjayasena@gmail.com 


\section{Keywords}

Audit Education, Audit Expectation Gap, Professional Auditors, Undergraduates

\section{Introduction}

Extant research indicates that the criticism of auditors and even litigation against auditors for failing to meet society's expectations is clearly harmful to the accounting and auditing professions (Porter et al., 2012; Ojo, 2009; Anderson \& Emander, 2005; Porter \& Gowthorper, 2004). Following the exposures of some large-scale dishonorable corporate reporting and accounting scandals such as Enron, WorldCom, and Xerox, public outcry mounted dramatically (Lin, 2004). On the other hand, it should be noted that the value of a financial statement audit relies on society having confidence in the audit concept and function (Ruhnke \& Schmidt, 2014; Institute of Chartered Accountants in England and Wales, 2008). However, due to the recent national and international accounting and auditing scandals, the performance of auditors has been spotlighted in the public domain attracting various comments and opinions (Moore \& Loewenstein, 2004). This situation presents itself as a case of 'Audit Expectation - Performance Gap' (AEG), which highlights the difference between the actual performance of auditors and society's expectations regarding their services (Porter et al., 2012; Lee \& Azham, 2008: Porter \& Gowthorper, 2004).

As business operations have become much more complex owing to globalization, cross-border transactions and large-scale industrial restructuring, the investing public has increasingly relied on auditors to monitor and assure the reliability of financial reporting (Terzungwe, 2012). Thus, the 'expectation gap' has emerged as the profession failed to respond adequately (Francis, 1994; Munter \& Ratcliffe, 1998; Power, 1998). Nonetheless, the 'expectation gap' in relation to auditor's responsibility is mainly a time lag effect. Further, Lee et al. (2009) reviewed reliability and credibility challenges to audit function and the auditing profession resulting large-scale corporate financial scandals in, and collapse of, many multinational corporations shortly after 'clean' audit reports were issued on them. Based on these observations, it could be emphasized that auditors and the profession must react sooner or later to narrow the gap (Dewing and 
Russell, 2001). This understanding is in line with Lee et al. (2009, p.14), who concluded that 'if the audit profession is to survive in the long term, remedies are desperately needed to restore the image of the auditing profession as a credible, independent, objective, professional evaluator of financial transactions and reports. Thus, the effort to re-establish the image of the auditing profession through narrowing the audit expectation gap is crucial'. Therefore, the audit expectation gap is critical to the audit profession as it impacts on the value of auditing and the reputation of auditors in modern society.

On the other hand, a number of studies subsequently concentrated on identifying ways of reducing such an audit expectation gap (Porter et al., 2012; Siddiqui, 2009; Monroe \& Woodliff, 1993). A number of tools were identified, namely, improvement of quality of auditing; enhanced audit education at university and professional levels; modification of the language in the audit engagement letter; and establishment of an oversight board (Sidani 2007; Best et al., 2001). It is noted that the effectiveness of audit education as a means of reducing this gap has been emphasized by a number of studies (Sikka et al., 1992; Humphrey et al., 1992). In a recent study, Sidani (2007) established the effect of audit education at universities and professional levels in reducing the audit expectation gap. Pierce and Kilcommins (1997) examined the effect of auditing education over reduction of the expectation gap via a questionnaire survey involving undergraduate students in Ireland; and found a significant reduction in the misunderstanding of audit regulations by students who have studied at least a single course on auditing. Further, Monroe and Woodliff (1993) examined the effect of education on students' perceptions of audit reports in Australia and found that auditing students' beliefs regarding the responsibility of auditors, the reliability of financial information and assurance about the future prospects of the company changed significantly with knowledge. It was found that more knowledgeable students expected a much lower level of responsibility of the auditor, less confidence on the reliability of financial statements and assurance over the future prospects of the company. Hughes et al., (1998) found the use of auditing scandals in classroom teaching to be beneficial in reducing unreasonable expectations. Further, Porter and Gowthorpe (2004) suggest that the recent accounting scandals could be incorporated in university auditing curricula to provide students with some 
exposure regarding real life auditing. This could reduce the unreasonable expectations of the users. These extant empirical studies suggest that education plays a significant role in narrowing the audit expectation gap.

There are a few extant studies that have explored audit expectation gap in the Sri Lankan context. However, these pertain to the period before 2005, and the applicability of the findings and inferences to later periods might be questionable as there have been significant changes in audit regulations in more recent times. Furthermore, the researchers of the present study did not observe extant studies that examined the effect of the audit education on the audit expectation gap in the Sri Lankan context.

Thus, based on the contemporary importance of the topic and dearth of studies on it in Sri Lanka, the present study attempts to assess the status of audit expectation-performance gap among auditors and the undergraduate students in the Sri Lankan context; and examine the effect of audit education at universities and other professional institutions on such gap, in the Sri Lankan context. By addressing these issues, the present study intends to contribute to the contemporary research gap in the local literature as well as provide information to make informed decisions by policy makers in the educational and regulatory fields.

The study is structured as follows. The next section discusses the extant literature on the audit expectation gap; models pertaining to such a gap and empirical studies that examine the impact of audit expectation on minimizing the gap. Then the next subsequent section elaborates the methodology adopted in achieving the objectives of this study, while emphasizing the research approach, sample design, details on the questionnaire development and analytical strategies adopted. Afterwards, the section on findings and discussion elaborates the findings secured by executing these testing strategies, and discusses these findings in relation with the extant studies. Finally, the conclusion of the study is presents the main findings, conclusions derived, limitations of this study and future research directions. 


\section{Literature Review}

\section{Audit Expectation Gap}

Humphrey et al. (1992) argued that 'audit expectation gap' is a debate fueled by major financial scandals which regularly place that audit function under the public microscope. In terms of definitions, Liggio (1974) defined 'Audit Expectation Gap' as the difference between the actual and the expected performance of auditors. This definition was further extended by the Cohen Commission on auditors' responsibilities in 1978, where the expectation gap was proposed to be represented by the gap between the performance of auditors and the expectations of the users of financial statements. On the other hand, Monroe and Woodliff in 1993 defined the expectation gap as the difference between the beliefs of auditors and the public concerning the auditors' responsibilities and duties assumed by auditors and messages conveyed by audit report. However, Porter in 1993 challenged the definitions used by Liggio (1974) and the Cohen Commission Report (1978), and argued that both definitions were too narrow as they failed to consider the possibility of substandard performance by auditors. Thus, she proposed that gap, more appropriately entitled 'the audit expectation-performance gap', to be defined as the gap between society's expectations of auditors and auditors' performance, as perceived by society; since, this gap gives rise to criticisms of auditors is that between what society expects from auditors and what it perceives it receives from them. Further, in terms of components of the audit expectations gap, the existing literature elaborates that the audit expectations gap consists of different components. In 1988, the Canadian Institute of Chartered Accountants (CICA, 1988) reported that the gap consists of three main components, which are: (1) unreasonable expectation by users (2) inadequate legislation, auditing and accounting standards and; (3) inadequate performance of auditors. In 1993, Porter refined the components reported by CICA (1988), and suggested that the expectation gap can be divided into two components, which consists of the performance gap and the reasonableness gap. Porter (1993, p.50) defined the 'performance gap' as the difference between 'what society can reasonably expect auditors to accomplish and what they are perceived to achieve'; while she defined the 'reasonableness gap' as the difference between 'what society expects auditors to achieve and what they can reasonably be expected to accomplish'. Porter (1993) further subdivided these gaps into 'deficient 
standards', i.e., the gap between the duties which can reasonably be expected of auditors and auditors' existing duties as defined by the law and professional promulgation, and 'deficient performance' gap, which is the gap between the expected standard of performance of auditors' existing duties and auditors' performance, as expected and perceived by the society (Figure 1).

\section{Figure 1: Porter Model}

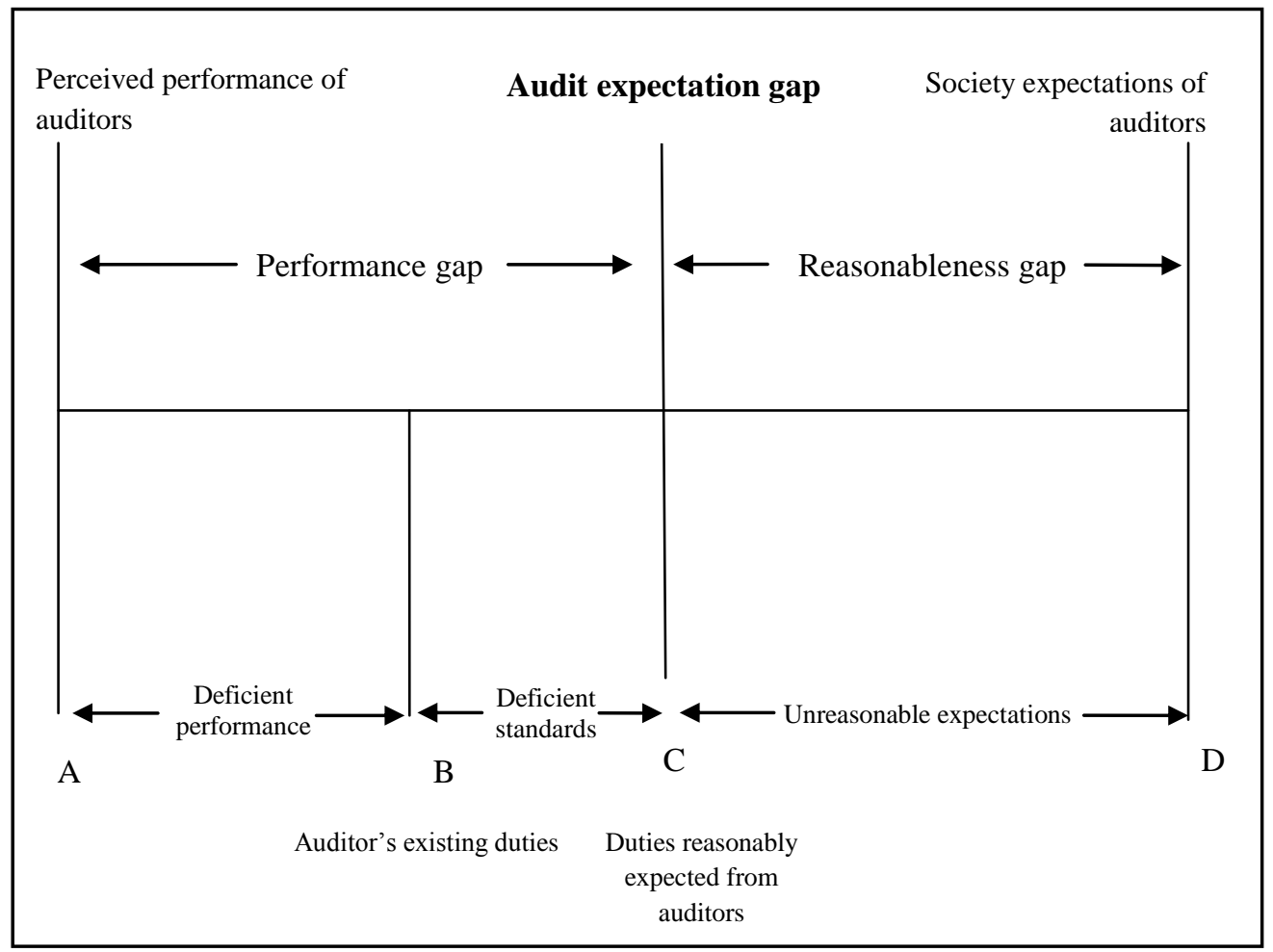

Source: Porter, 1993

As indicated in Figure 1, the 'audit expectations gap' ranges from the left to right (from point ' $A$ ' to ' $D$ '). This gap represents the difference between what is perceived of the auditors' performance with what is expected of auditors by the society. Point ' $\mathrm{B}$ ' represents auditors existing duties and point ' $\mathrm{C}$ ' represents auditors' performance as required by the present professional standards. The range from points ' $C$ ' to ' $D$ ' represents the 
public expectations that go beyond the present professional standards used by auditors. This gap is known as the 'unreasonableness gap'. The range from points ' $A$ ' to ' $C$ ' represents the perceived sub-standard performance of auditors by the public. Porter (1993) tested and analyzed the structure, composition and extent of the audit expectation-performance gap using four interest groups in New Zealand, i.e., the auditors, auditees, financial community and the general public. Porter examined the opinion of these interest groups on the auditors' existing duties, the standard of performance of these duties, and the duties that auditors should perform. Altogether, thirty suggested duties were tested, and the results indicated that twenty-five suggested duties of auditors contributed to the audit expectationsperformance gap. Specifically, seven duties were due to a deficient performance (e.g., expressing doubts in the audit report about the company's continued existence), eight were due to deficient standards (e.g., reporting to a regulatory authority on suspicious of fraud) and ten were due to unreasonable expectations of society (e.g., providing a guarantee that the audited financial statements are accurate). Overall, Porter concluded that 16 per cent of the total gap arose from sub-standard performance of auditors, 50 per cent from deficient standards and 34 per cent from unreasonable expectations. Porter then constructed the model of the audit expectationperformance gap indicated in Figure 1.

In terms of empirical evidence on the existence of the gap in recent times, Lee et al., (2007) examined whether an expectation gap exists in Malaysia among the auditors, auditees and audit beneficiaries in relation to the auditors' duties. Their findings indicate the existence of such an expectation gap, and thus, they further analyzed the nature of the gap using Porter's (1993) framework. The study showed that the auditees and audit beneficiaries placed much higher expectations on the auditors' duties when compared with what auditors have perceived their duties to be. Further, findings indicated the existence of unreasonable expectations of the part of users; deficient standards of auditing in Malaysia; and deficient performance of auditors. Similarly, Chowdhury and Innes (1998) revealed important differences between the auditors and the audit report users in such important areas as auditor accountability, auditor independence, auditor competence, truth and fairness of the reported information and the role of the performance audit.In another comparable study undertaken by Troberg and 
Viitanen (1999) on the audit expectation-performance gap using the Porter's (1993) classification, 35 duties were identified as the existing and suggested duties of an auditor in Finland. In this study, some areas of duties recognized by Porter (1993) were included and the results of the study showed that the factors which contribute extensively to the expectation gap in Finland are: the auditor's responsibility with regard to fraud detection and reporting, detecting and reporting illegal acts by employees that affect the company's accounts, going-concern reporting, and correcting the financial statements when necessary. Thus, this section concludes by indicating the contemporary existence of an audit expectation gap confirming the model suggested by Porter (1993).

\section{Role of Audit Education in Minimizing the Audit Expectations Gap (AEG)}

Having identified and defined the audit expectation gap, a number of researchers have suggested means of reducing the gap (Porter \& Gowthorpe, 2004; Shaikh \& Talha, 2003) which include increased monitoring of auditors' performance; improving quality control in the audit firms; enhanced education; discussing, establishing, and disclosing materiality standards in the audit report; modifying the language in the audit engagement letters; and creation of an independent audit oversight agency; and other measures.

Particularly, Porter and Gowthorpe (2004) recommended that increased education for auditors is a better means of reducing the performance gap. They suggested that further education should be required for all existing and trainee auditors to make sure that they understand their responsibilities under the corporation law. They also suggest that the auditors should also be made aware of the standard of work they are expected to perform. Furthermore, the effectiveness of education as a means of reducing the audit expectation gap has been emphasized by a number of studies (Sikka et al., 1992; Humphrey et al., 1992). Moreover, Salehi and Rostami (2009) provided international evidence on the nature, causes and prevalence of such a gap across major world economies and associated the gap to 'overexpectation' and 'lack of knowledge' by financial statement users about auditors' role and responsibilities. It could therefore be argued that users' ignorance, over-expectation and lack of knowledge are by-products of lack 
of education, and any agenda for reducing the gap which are not targeted at increasing users' knowledge and awareness of the nature and limitations of audit function and outcome may not go far in resolving the problems of audit expectation gap. Furthermore, previous studies (Adeyemi \& Uadiale, 2011; Appah, 2010; Rehana, 2010; Javed et al., 2009; Pierce \& Kilcommins, 1996) provide evidence on the relevance of audit education in minimizing audit expectation gap by exposing financial information users to, and helping them, appreciate the role of auditors from the statutorily defined perspective. Pierce and Kilcommins (1996) noted the existence of conflicting views in literature regarding the role of auditing education in narrowing this gap and found a significant reduction in all elements of misunderstanding gap for those groups who studied either a module or a course in auditing during the period. Javed et al. (2009) used survey responses of auditors, bankers and students in Bangladesh to provide evidence that audit education significantly reduces the expectation gap, especially in the area of audit reliability. Rehana (2010) also investigated the role of auditing education in narrowing this gap in Bangladesh and provided evidence that the provision of auditing subjects as part of business degree programmes significantly contributes to narrowing expectation gap resulting from misunderstanding of audit regulations. Adeyemi and Uadiale (2011), while confirming the existence of audit expectation gap in Nigeria, particularly on issues concerning auditor's responsibilities, recommend educating the public about the objects of an audit, auditors' role and responsibilities as a strategy for narrowing the expectation gap. Further, some studies on audit education see education as having a fundamental role to play in resolving user misconceptions regarding the role and responsibilities of external auditors (Beck, 1973; Mednick, 1986). Others have argued that one obvious way to narrow the gap between the profession's understanding of its responsibilities and users' expectations is to better educate the public on the limitations of an audit (Mednick, 1986).

According to the extant research discussed above, audit education involves the process of enlightening, training and creating awareness on the statutory and other duties of the auditor to users of financial information and the general public with the aim of improving their level of understanding of the functions of an audit process; and subsequent bridging the gap between expectations of the public and performance of the auditor. Extant studies 
discussed have supported that the knowledge of the users influences the size of the expectation gap, and audit education could narrow the audit expectation gap. The next section discusses on the methodology suggested in achieving the objectives of the present study.

\section{Methodology}

This section elaborates the methodology adopted in addressing the research objectives discussed under Section 1: Introduction of this study, i.e., to examine the status of an audit expectation-performance gap among auditors and undergraduate students; and to examine the effect of audit education at universities and other professional institutions on the audit expectation gap, in the Sri Lankan context.

A positivistic research approach which is deemed appropriate in achieving the aforementioned objectives are adopted, which is also supported by extant literature (Lee et al., 2007; Lin \& Chen, 2004; Troberg $\&$ Viitanen, 1999). The population of the study includes practicing auditors (i.e., audit partners, senior audit managers, audit managers, assistant audit managers, audit supervisors and senior auditors) in Sri Lanka and third-year undergraduates of a regional national university who follows a management degree programme specializing in accountancy and finance, business management, tourism and hospitality and business information technology. Questionnaires were administered among 100 practicing auditors (the response rate was 36 per cent) and 300 undergraduates (the response rate was 89 per cent) selected on a random basis. Undergraduate students comprised of students,

i. Who did not follow any auditing course in the degree (denoted as CAT1 in this study),

ii. students who only followed a basic auditing course in the degree programme (denoted as CAT2 in this study), and

iii. students who followed an advanced auditing course in the degree programme (denoted as CAT3 in this study).

These categories were identified to test the effect of audit education on the audit expectation gap. 
In collecting data, a structured questionnaire was administered among the practicing auditors and the undergraduates, which is constructed based on the extant literature (Lee et al. 2007; Troberg \& Viitanen, 1999; Porter, 1993). Part One in questionnaire was on demographic information of the respondents. Part Two in the structured questionnaire listed 30 duties (i.e., duties 1 to 7: captures deficient standards gap; 8 to 15: deficient performance gap; and 15 to 30: unreasonable expectation gap) of auditors (Annexure I) as identified by Porter (1993), and the opinions of the respondents were obtained as to whether such duties are auditors' existing duties (Section 01), the level of auditors' performance of these duties (Section 02), and whether such duties should be performed by the auditors (Section 03). Accordingly, Section 01 is on whether the listed duty 'Is' or 'Is not an existing responsibility' of auditors, or whether the respondent is 'Not sure', which were coded as $+1,-1$ and 0 , respectively. When the mean of an interest group's responses is positive, this indicates that the group considered the responsibility is, or should be, (as applicable), a responsibility of auditors. Then, if a respondent had considered a particular duty as an 'existing duty of auditors' (by indicating 'Is' under Section 01), then under Section 2, the respondent is asked on 'how well is it performed?'. The respondents were to rate such using a Likert scale from 'poorly' (1) to 'excellently' (5) performed. Finally, Section 03 inquires on 'Should the duty be performed by auditors?'. For the purpose of answering this section, the options 'Yes' (+1), 'No' (-1) and 'Not certain (0) were provided. Once the questionnaire was formulated, it was provided to two experts in the academic and professional fields and their expert opinions were used to revise the questionnaire. Finally, the questionnaire was pilot tested before it was circulated among the professional auditors and undergraduates. These measures were taken to ensure the validity of the questionnaire.

In terms of the analysis, descriptive statistics is generated in understanding the demographic profiles of the audit professionals and different categories of the undergraduates. Then, the independent sample $t$ test was used to test the differences of opinion between the groups and identify the status of the audit expectation gap as well as to examine whether audit education could minimize the gap. If significant differences are found between auditors and each student group, it may be claimed that 
an expectation gap exists. Further, if the $t$-test results found that there is no statistically significant difference between students who had been exposed to audit education as compared to students who had no exposure, the positive effect of audit education on minimizing the audit expectation gap could be established. ${ }^{1}$ The next section presents the findings secured by following the methodology suggested under this section.

\section{Analysis and Discussion}

This section presents the results of the analyses suggested under the earlier section, which also provides a discussion on these findings.

\section{Descriptive Analysis}

As discussed under the earlier section, responders for this study are practicing auditors and undergraduate students in a regional national university. As presented in Table 1, the majority is audit supervisors (55.6 per cent) and the minority consists of senior audit managers (2.8 per cent); while 75 per cent of the practicing auditors are from the non-big 3 audit firms. In terms of gender, the majority of the practicing auditors consist of males (72.2 per cent).

The majority of auditors responded had quite strong academic backgrounds, where 72.3 per cent were having a first degree. In terms of duration of audit experience, the majority of auditors had a work experience between 3 to 5 years. Further, it is noted that more than 80 per cent of the professional auditors represent the age group between 21 years to 40 years.

\footnotetext{
${ }^{1}$ In addition to the independent sample $t$-tests, the non-parametric Mann-Whitney $\mathrm{U}$ tests will be performed as additional analyzes.

${ }^{2}$ Qualitatively similar findings of the independent sample $t$-tests reported under
} 
Table 1: Descriptive Analysis - Professional Auditors

\begin{tabular}{|c|c|c|c|}
\hline Variables & Categories & $N$ & $\%$ \\
\hline \multirow{7}{*}{ 1. Current status } & Audit Partners & 05 & 13.9 \\
\hline & Senior Audit Manager & 01 & 2.8 \\
\hline & Audit Managers & 06 & 16.7 \\
\hline & Assistant Audit Managers & 02 & 5.6 \\
\hline & Audit Supervisors & 20 & 55.6 \\
\hline & Senior Auditors & 02 & 5.6 \\
\hline & Total & 36 & 100 \\
\hline \multirow{3}{*}{$\begin{array}{l}\text { 2. A member of big } 3 \text { audit } \\
\text { firm }\end{array}$} & Yes & 09 & 25.0 \\
\hline & No & 27 & 75.0 \\
\hline & Total & 36 & 100.0 \\
\hline \multirow{3}{*}{ 3. Gender } & Male & 26 & 72.2 \\
\hline & Female & 10 & 27.8 \\
\hline & Total & 36 & 100.0 \\
\hline \multirow{4}{*}{$\begin{array}{l}\text { 4. Highest educational } \\
\text { qualification }\end{array}$} & GCE A/L & 07 & 19.4 \\
\hline & Graduate & 26 & 72.3 \\
\hline & $\mathrm{MBA} / \mathrm{MSc}$ & 03 & 8.3 \\
\hline & Total & 36 & 100 \\
\hline \multirow{6}{*}{ 5.Work experience } & Less than one year & 03 & 8.3 \\
\hline & Between 1-3 & 23 & 63.9 \\
\hline & Between 3-5 & 03 & 8.3 \\
\hline & Between 5-8 & 04 & 11.1 \\
\hline & More than 8 & 03 & 8.3 \\
\hline & Total & 36 & 100 \\
\hline \multirow{6}{*}{ 6.Duration of audit experience } & None & 03 & 8.3 \\
\hline & Between 1-3 & 18 & $5 . .0$ \\
\hline & Between 3-5 & 08 & 22.2 \\
\hline & Between 5-8 & 03 & 8.3 \\
\hline & More than 8 & 04 & 11.1 \\
\hline & Total & 36 & 100 \\
\hline \multirow{6}{*}{ 7. Age level } & Between 21-30 & 20 & 55.6 \\
\hline & Between 31-40 & 10 & 27.8 \\
\hline & Between 41-50 & 02 & 5.6 \\
\hline & Between 51-60 & 00 & 00 \\
\hline & Between 61-70 & 04 & 11.1 \\
\hline & Total & 36 & 100 \\
\hline
\end{tabular}

Source: Constructed by Authors 
Descriptive analysis of undergraduates is depicted in Table 2. The undergraduates selected follow the degree programmes: B.Sc. (Accountancy \& Finance) Sp. Degree [ACF]; B.Sc. (Business Management) Sp. Degree $[\mathrm{BM}]$; B.Sc. (Tourism and Hospitality) Sp. Degree [THM]; and B.Sc. (Business Information Technology) Sp. Degree [BIT], and the majority (38.1 per cent) are from the BM Degree programme. In terms of gender, female undergraduates are slightly higher (54 per cent) than the male undergraduates. Approximately 51 per cent of them had followed a professional course in accounting (such as AAT, CIMA, CA Sri Lanka, CMA or ACCA), and the majority (82.6 per cent) had got no work experience (i.e., practical training). As expected, the age of the undergraduates ranges from 21 to 26 years.

Table 2: Descriptive analysis - Undergraduates

\begin{tabular}{llcc}
\hline Variables & Categories & $\boldsymbol{N}$ & $\mathbf{\%}$ \\
\hline 1. Degree & ACF* & 95 & 35.5 \\
& BM & 102 & 38.1 \\
& THM & 33 & 12.3 \\
& BIT & 38 & 14.2 \\
& Total & $\mathbf{2 6 8}$ & $\mathbf{1 0 0 . 0}$ \\
\hline 2. Gender & Male & 123 & 45.9 \\
& Female & 145 & 54.1 \\
& Total & $\mathbf{2 6 8}$ & $\mathbf{1 0 0 . 0}$ \\
\hline 3. Professional course in & Followed & 155 & 51.3 \\
accounting & Not followed & 113 & 48.7 \\
& Total & $\mathbf{2 6 8}$ & $\mathbf{1 0 0 . 0}$ \\
\hline 5. Work experience & No & 257 & 82.6 \\
& With experience & 11 & 17.4 \\
& Total & $\mathbf{2 6 8}$ & $\mathbf{1 0 0 . 0}$ \\
\hline 6. Age level & Between 21-23 & 191 & 72.1 \\
& Between 24-26 & 74 & 27.9 \\
& Total & $\mathbf{2 6 5}$ & $\mathbf{1 0 0 . 0}$ \\
\hline
\end{tabular}

*ACF: B.Sc. (Accountancy \& Finance) Sp. Degree;

BM : B.Sc. (Business Management) Sp. Degree;

THM: B.Sc. (Tourism and Hospitality) Sp. Degree;

BIT: B.Sc. (Business Information Technology) Sp. Degree.

Source: Constructed by Authors 
Table 3: Status on following an Auditing Course/s in Degree Programme or Professional Course

\begin{tabular}{lcccc}
\hline & \multicolumn{2}{c}{ No. of students } & & \\
\cline { 2 - 3 } & $\begin{array}{c}\text { Under the } \\
\text { Degree } \\
\text { Programmes }\end{array}$ & $\begin{array}{c}\text { Under a } \\
\text { Professional } \\
\text { Course }\end{array}$ & Total & \% \\
\hline $\begin{array}{l}\text { Not followed any } \\
\text { auditing course }\end{array}$ & 128 & 163 & 291 & 61.1 \\
$\begin{array}{l}\text { (CAT1) } \\
\text { Followed a basic } \\
\text { auditing course only } \\
\text { (CAT2) }\end{array}$ & 98 & 68 & 166 & 34.9 \\
$\begin{array}{l}\text { Followed an } \\
\text { advanced auditing } \\
\text { course only (CAT3) }\end{array}$ & 15 & 04 & 19 & 4.0 \\
\hline \begin{tabular}{l} 
Total \\
\hline
\end{tabular} & 241 & 235 & 476 & 100 \\
\hline
\end{tabular}

Source: Constructed by Authors

Table 3 depicts the status of undergraduates on following an auditing course/s in their respective undergraduate degree programmes or/and in a professional accounting course. It is observed that the majority (61.1 per cent) had not followed any auditing course unit either in the university or under a professional accounting course. On the other hand, 34.9 per cent of the students had followed only a basic auditing course, while 4 per cent had followed an advanced auditing course.

\section{The Impact of Audit Education on the Audit Expectation Gap}

This section elaborates the impact of audit education on the audit expectation gap by performing independent sample $t$-tests that compares expectations of undergraduates who had not followed any auditing course (CAT1), who had followed a only a basic auditing course (CAT2), and who had followed an advanced auditing course (CAT3) with the expectations that of professional auditors. The results are indicated in Tables 4 to 6 . 
Table 4: Independent Sample $t$-test - Students who had not followed an Audit Course (CAT1) and Professional Auditors

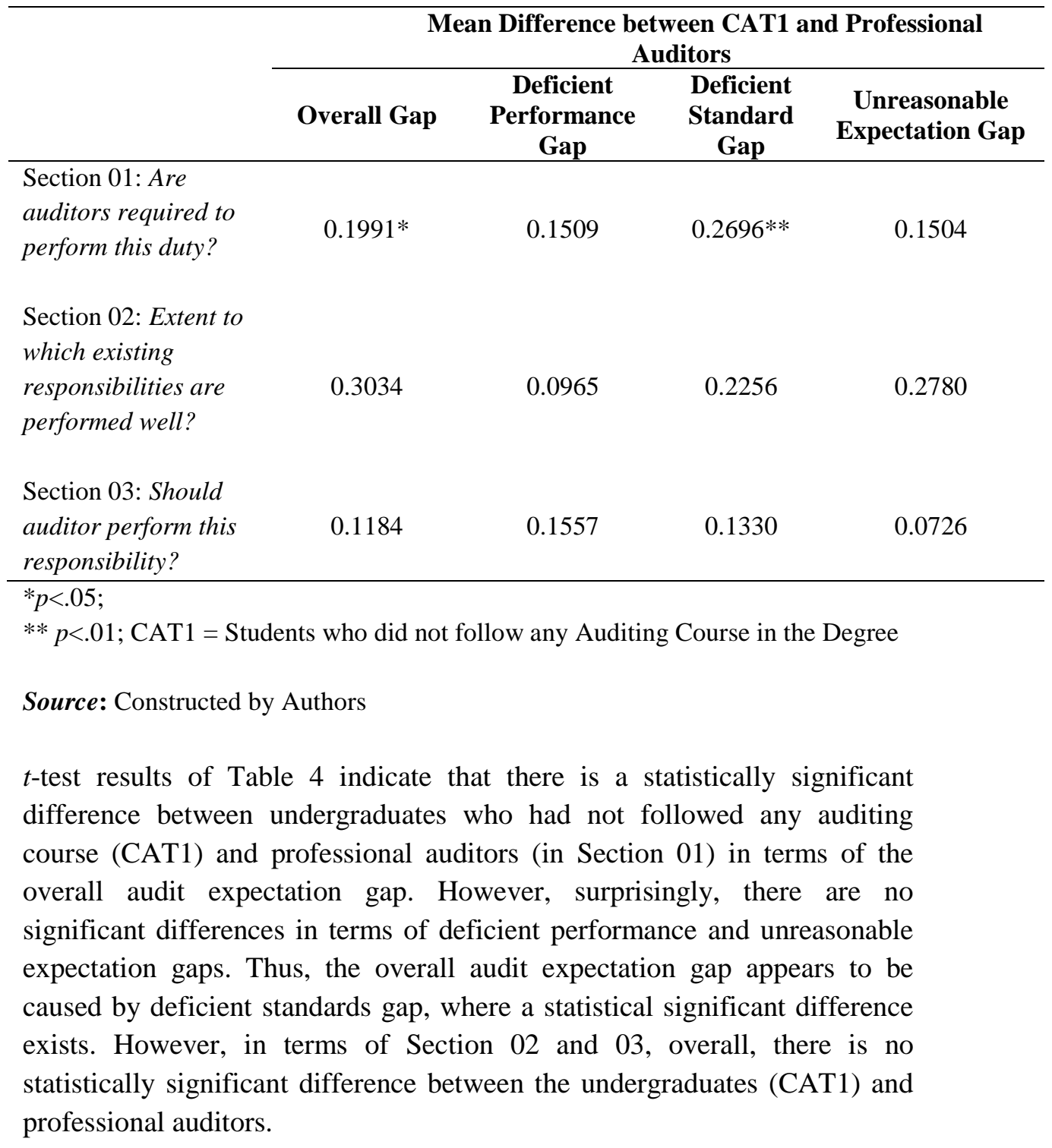

The results of the independent sample $t$-test that compares the expectations between undergraduates who had followed a basic audit course (CAT2) and professional auditors on Sections 01, 02 and 03 are presented in Table 5. It is observed that under Section 01, the overall, deficient 
performance and deficient standard gaps are having a statistically significant difference between the expectations of undergraduates (CAT2) and professional auditors, which is also observed under Section 03. This is quite surprising when compared with the results depicted under Table 4 above, where the undergraduates who had not undertaken any auditing course (CAT1) had no deficient performance or unreasonable expectation gaps on a statistically significant basis compared with professional auditors' expectations. However, surprisingly, as depicted in Table 5, the CAT2 undergraduates who had followed a basic course in auditing has even indicated an unreasonable expectation gap under Section 03 in addition to having overall, deficient performance and deficient standards gaps under Section 01 and 03.

Table 5: Independent Sample $t$-test - Students who had followed a Basic Audit Course(CAT2) and Professional Auditors

Mean Difference between CAT2 and Professional Auditors

\begin{tabular}{cccc}
\cline { 2 - 4 } Overall & Deficient & Deficient & Unreasonable \\
Gap & Performance & Standard & Expectation \\
& Gap & Gap & Gap \\
\hline
\end{tabular}

Section 1: Are

auditors required to perform this duty?
$0.2520 * *$
$0.2220^{*}$
$0.3060 * *$
0.1629

Section 2: Extent to

which existing

responsibilities are

0.0140

0.05838

0.1484

$-0.1429$

performed well?

Section 3: Should

auditor perform this

$0.2264 * *$

$0.2004^{*}$

$0.2042 *$

$0.2040 *$

responsibility?

$* p<.05 ; * * p<.01$

CAT2 = Students who only followed a Basic Auditing Course in the Degree Programme

Source: Constructed by Authors 
These findings may indicate that the basic audit courses delivered under the undergraduate or/and professional courses may not have been adequate in clarifying the duties of auditors leading to the creation of these kinds of expectation gaps.

Table 6: Independent Sample $t$-test - Students who had followed an Advanced Audit Course (CAT3) and Professional Auditors

Mean Difference between CAT3 and Professional

Auditors

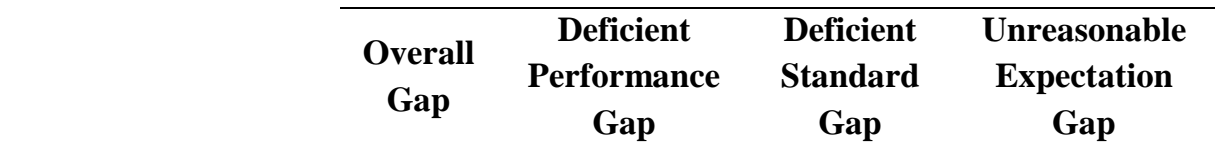

Section 1: Are

auditors required to

perform this duty?

$\begin{array}{llll}0.2149 & 0.3039^{*} & 0.3271^{*} & 0.1244\end{array}$

Section 2: Extent to

which existing

responsibilities are

$0.6965^{*} \quad 0.2550$

$0.9360^{*}$

0.7430

performed well?

Section 3: Should

auditor perform this

0.1886

0.1519

0.0368

0.1816

responsibility?

$* p<.05 ; * * p<.01$

CAT3 $=$ Students who followed an Advanced Auditing Course in the Degree Programme

Source: Constructed by Authors

The comparison between the expectations of undergraduates who had followed an advanced auditing course (CAT3) and professional auditors are depicted in Table 6. It is clearly visible the overall audit expectation and unreasonable expectation gaps are not statistically significant both under Sections 01 and 03. Although, under Section 01, there yet exist a performance gap and standard gap, these gaps are not significant under Section 03. These findings indicate that students after following an advanced auditing course (CAT3) have improved their knowledge and awareness leading to the disappearance of overall audit expectation gap 
including the unreasonable expectation gap. These findings are consistent with the findings of the extant studies (Siddiqui, 2009; Porter \& Gowthorpe 2004; Monroe \& Woodliff, 1993; Sikka et al., 1992; Humphrey et al., 1992), which find a positive impact of audit education in minimizing the audit expectation gap. ${ }^{2}$

\section{Conclusion}

The main objective of this research study was to examine the status and impact of audit education on the audit expectation gap, as existence of such a gap was noted to be harmful to the accounting and auditing profession in the contemporary extant literature (Porter et al., 2012; Ojo, 2009; Anderson \& Emander, 2005). Accordingly, in order to examine the expectation gap, undergraduates of a regional national university (i.e., in three categories as: undergraduates who had not followed an auditing course, who had followed a basic auditing course, and who had followed an advanced auditing course) and professional auditors were selected and a questionnaire survey that included statements on the duties of the auditors was administered among them. In terms of the testing strategy, the independent sample $t$-test was performed to test differences of opinion between the respective groups. The findings indicated a significant difference $(p<.05)$ between CAT1 students (i.e., students who had not followed an audit course) and auditors on the opinions about auditors' existing duties. Further, a significant difference $(p<.05)$ was also noted between CAT2 students (i.e., students who had only followed only a basic auditing course) and auditors for both auditors' existing duties and the duties that auditors should perform. These findings clearly indicate the existence of an audit expectation gap. On the other hand, there was no significant difference $(p>.05)$ found between CAT3 students (i.e., students who had followed an advanced auditing course) and auditors with regard to auditors' existing duties and the duties that auditors should perform. These findings indicate that students after following an advanced auditing course have improved their knowledge and awareness leading to the disappearance of an audit expectations gap; and signify that the audit education could minimize such a gap. Thus, based on the findings of this study, it could be concluded that of an existence of an audit expectation gap

\footnotetext{
${ }^{2}$ Qualitatively similar findings of the independent sample $t$-tests reported under Tables 4, 5 and 6 were obtained under the Mann-Whitney U test (not tabulated).
} 
in the Sri Lankan context; and that audit education had an effect in reducing the such a gap. These findings are consistent with the extant literate (Siddiqui, 2009; Porter \& Gowthorpe 2004; Monroe \& Woodliff, 1993). In terms of policy implications, the findings of this study are also expected to have significant educational policy implications. The related educational institutions and professional bodies should examine their curricula for the adequacy and appropriateness in clarifying the auditor's responsibilities as this study found that the undergraduates who had followed a basic auditing course was no different than undergraduates who had not followed any auditing course in terms of the audit expectation gap. The results indicated that only an advanced auditing course had resulted in minimizing such a gap (particularly the unreasonable expectation gap). Therefore, a through scrutiny should be undertaken by these institutions and appropriate remedial actions should be taken to enlighten the students with adequate knowledge and experience with auditors' duties.

In terms of future research, the expectation gap among more stakeholders could be undertaken by broadening the scope of the present study. Further, the impact of other factors other than audit education in minimizing the gap could be looked into.

\section{Acknowledgement}

This paper was presented at the Annual Research Symposium of the Faculty of Graduate Studies on "Sustainable Development for National Reconciliation" held at the Senate Hall, University of Colombo on $14^{\text {th }}$ October 2016. We would like to acknowledge the reviewers and other academics for their valuable comments and guidance to improve this research paper.

\section{References}

Adeyemi, S.B., \& Uadiale, O.M. (2011). An empirical investigation of audit expectation gap in Nigeria. African Journal of Business Management, 5(19), 7964-7971.

Adresson, C., \& Emander, C. (2005). The new auditing standards in Sweden, (unpublished thesis, Golebung University). Sweden.

Appah, E. (2010). An evaluation of audit expectation gap: Issues and challenges. International Journal of Economic Development Research and Investment, $1(2 \& 3), 129-141$. 
Beck, G.W. (1973). Public accountants in Australia - Their social role. Australiain Accounting Research Foundation, Melbourne.

Best, P., Buckby, S., \& Tan, C. (2001). Evidence of the audit expectation gap in Singapore. Managerial Auditing Journal, 16(3), 134-144.

Canadian Institute of Chartered Accountants (CICA) (1988). Report of the commission to study the public's expectations of audits (Macdonald Commission). Toronto: Canadian Institute of Chartered Accountants.

Chowdhury, R.R., \& Innes, J. (1998). A qualitative analysis of the audit expectations gap in the public sector of Bangladesh. International Journal of Auditing, 247-266.

Commission on Auditors' Responsibilities (Cohen Commission) (1978). Report, conclusions and recommendations. American Institute of Certified Public Accountants, New York.

Dewing, I., \& Russell, P. (2001). Financial reporting accounting issues The expectations gap. Accountancy, 128(8), 94-98.

Francis, J. (1994). Discussion of lawsuits against auditors. Journal of Accounting Research, 32, 95-102.

Javed, S., Taslima, N., \& Aklema, C. L. (2009). The audit expectations gap and the role of audit education: The case of an emerging economy. Managerial Auditing Journal, 24(6), 564-583.

Hughes, J. F., Humphrey, C., \& Turley, S. (1998). Learning from mistakes? Using corporate scandals to enhance audit teaching. International Journal of Auditing, 2(2), 89-101.

Humphrey, C.G., Moizer, P., \& Turley, W.S. (1992). The audit expectations gap in Britain: An empirical investigation. Accounting and Business Research, 23(Sup. 1), 395-411.

Institute of Chartered Accountants in England and Wales. (2008). Evolution stakeholder expectations of audit. Institute of Chartered Accountants in England and Wales, 4-20.

Lee, T.H., Gloeck, D., \& Palaniappan, A.K. (2007). Audit expectation gap: An empirical study in Malaysia. Southern African Journal of Accountability and Auditing Research, 7, 1-15.

Lee, T.H., \& Azham, M. A. (2008). The evolving role of auditor: Where do we go from here? Accountants Today, 3, 18-22.

Lee, T.H., Ali, A.M., \& Kandasamy, S. (2009). Towards reducing audit expectation gap: Possible mission. Accountants Today, 12-22.

Liggio, C.D. (1974). The expectation gap: The accountant's legal Waterloo. Journal of Contemporary Business, 3, 27-44.

Lin, Z.J. (2004). Auditor's responsibility and independence: Evidence from China. Research in Accounting Regulation, 17, 167-190. 
Lin, Z. J., \& Chen, F. (2004). An empirical study of audit 'expectation gap' in the People's Republic of China. International Journal of Auditing, 8, 93-115.

Mednick, R. (1986). The auditor's role in society: A new approach to solving the perception gap. Journal of Accountancy, 161(2), 70-74.

Monroe, G.S., \& Woodliff, D.R. (1993). The effect of education on the audit expectation gap. Accounting and Finance, 33, 59-76.

Moore, D.A., \& Loewenstein, G. (2004). Self-interest, automaticity, and the psychology of conflict of interest. Social Justice Research, 17(2), 189-202.

Munter, P., \& Ratcliffe, T.A. (1998). Auditor's responsibility for detection of frauds. The National Public Accountants, 43(7), 26-28.

Ojo, M. (2009). Objectivity and independence: The dual roles of external auditor. Journal of Forensic \& Investigative Accounting, 6, 200-224.

Pierce, B., \& Kilcommins, M. (1997). The audit expectation gap: The role of auditing education. Dublin City University Business School Research Papers Series No. 13, Dublin City University Business School, Ireland.

Porter, B.A. (1993). An empirical study of the audit expectationPerformance gap. Accounting and Business Research, 24(93), 49-68.

Porter, B., Ó hÓgartaigh, C., \& Baskerville, R. (2012). Audit expectationperformance gap revisited: Evidence from New Zealand and United Kingdom part 1: The gap in New Zealand and the United Kingdom in 2008. International Journal of Auditing, 16, 101-129.

Porter, B.A., \& Gowthrope, C. (2004). Audit expectation-Performance gap in the United Kingdom in 1999 and comparison with the gap in New Zealand in 1989 and 1999, Institute of Chartered Accountants of Scotland Edinburgh.

Power, M. (1998). Auditor liability in context. Accounting, Organizations and Society, 23(1), 77-79.

Rehana, F. (2010). An Empirical study on audit expectation gap: Role of auditing education in Bangladesh. Munich Personal RePEc Archive (MPRA) - Paper 22708, Standford University.

Ruhnke, K., \& Schmidt, M. (2014). Forthcoming misstatements in financial statements: the relationship between inherent and control risk factors and audit adjustments. Auditing: A Journal of Practice \& Theory, 44(5), 72-601.

Salehi, M., \& Rostami, V. (2009). Audit expectation gap: International evidence. International Journal of Academic Research, 1(1), 40-146.

Shaikh, J., \& Talha, M. (2003). Credibility and expectation gap in reporting on uncertainties. Managerial Auditing Journal, 18(6/7), 517-529. 
Sidani, Y.M. (2007). The audit expectation gap: Evidence from Lebanon. Managerial Auditing Journal, 22(3), 288302.

Siddiqui, J. (2009). The audit expectations gap and the role of audit education: The case of an emerging economy, Managerial Auditing Journal, 24(6), 564-583.

Sikka, P., Puxty, A.G., Wilmott, H., \& Cooper, C. (1992). Eliminating the expectations gap?. Research Report No. 28, Chartered Association of Certified Accountants, London.

Terzungwe, N. (2012). Expected benefits of implementing global accounting standards by Nigerian business entities. International Journal of Business and Management, 7(15), 98-104.

Troberg, P., \& Viitanen, J. (1999). The audit expectation gap in Finland in an international perspective, Research Report, Swedish School of Economics and Business Administration, Helsinki, Finland.

\section{Appendix 1: Part B: Duties of the Questionnaire}

\section{Please complete Sections 1, 2 and 3.}

Section 1: Please complete Section 1 by ticking $(\sqrt{ })$ the appropriate number to indicate whether you think the listed responsibility 'IS' or 'IS NOT AN EXISTING RESPONSIBILITY' of auditors, or whether you are 'Not Sure'.

Section 2: If you ticked 'Yes' in Section 1, please complete Section 2 by ticking $(\sqrt{ })$ the appropriate number to indicate how well, as you think, auditors perform the given responsibility using the given scale.

Please complete Section 3 by ticking $(\sqrt{ })$ the appropriate number to indicate whether you think the listed responsibility 'SHOULD' or 'SHOULD NOT BE' performed by auditors, or whether you are 'Not Sure'. 


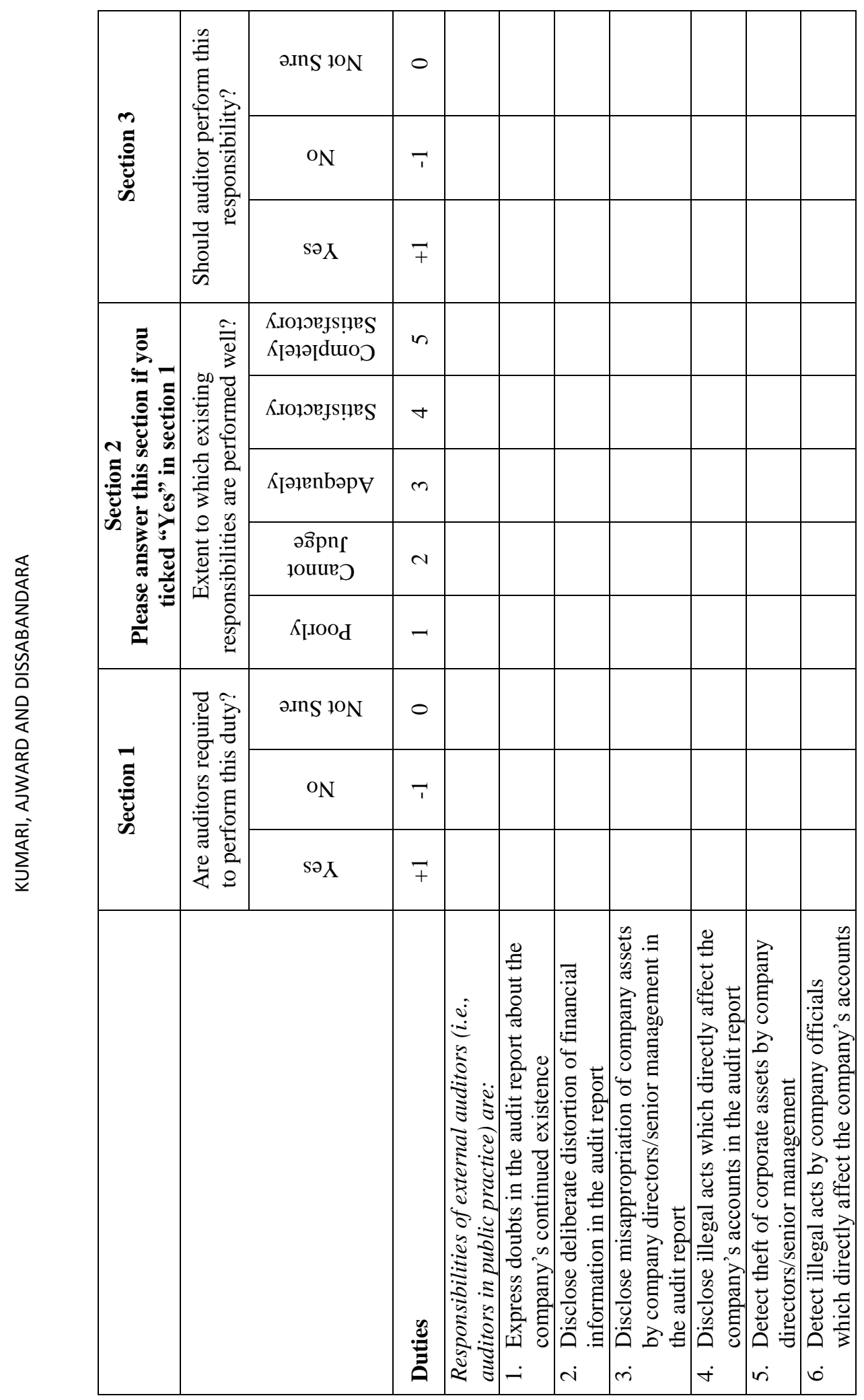




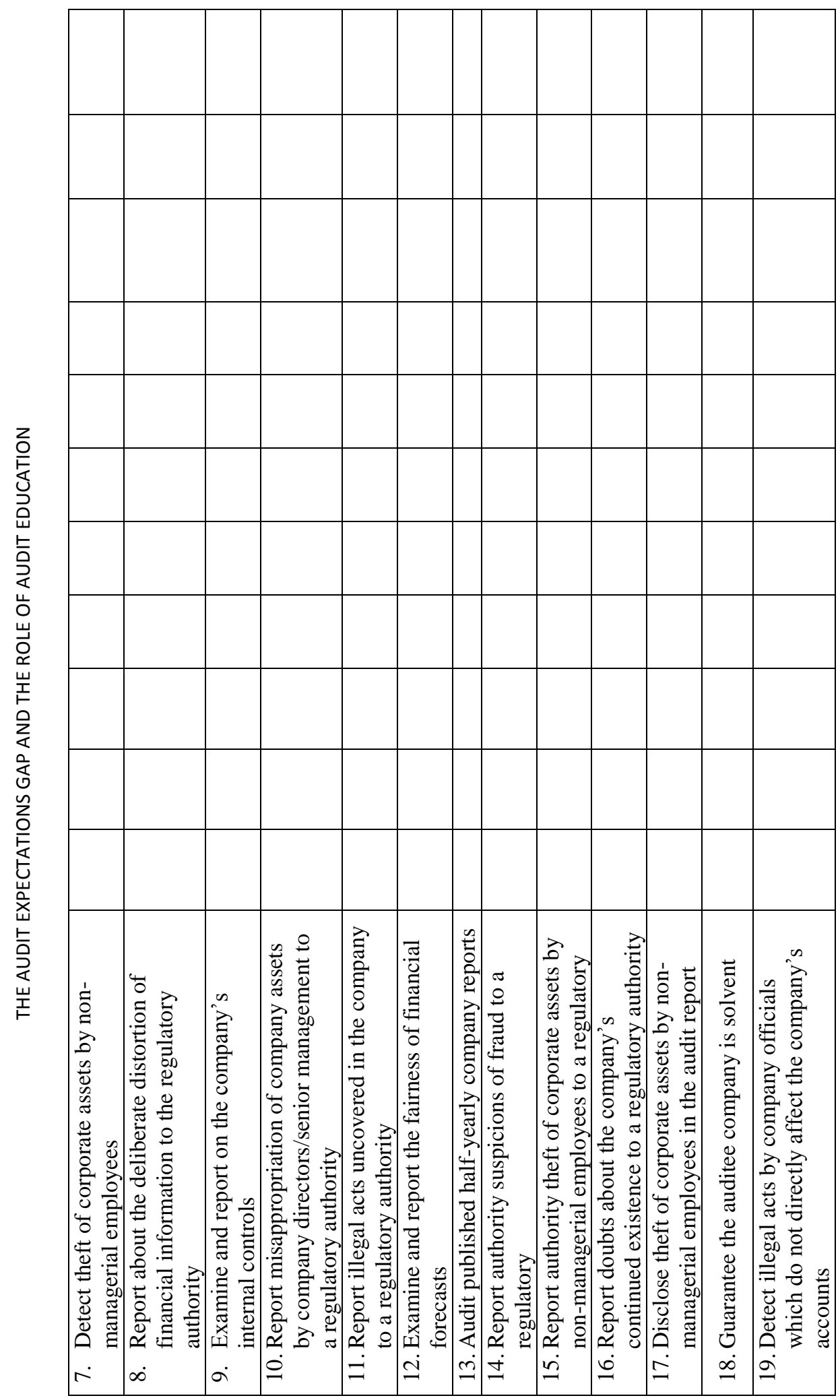




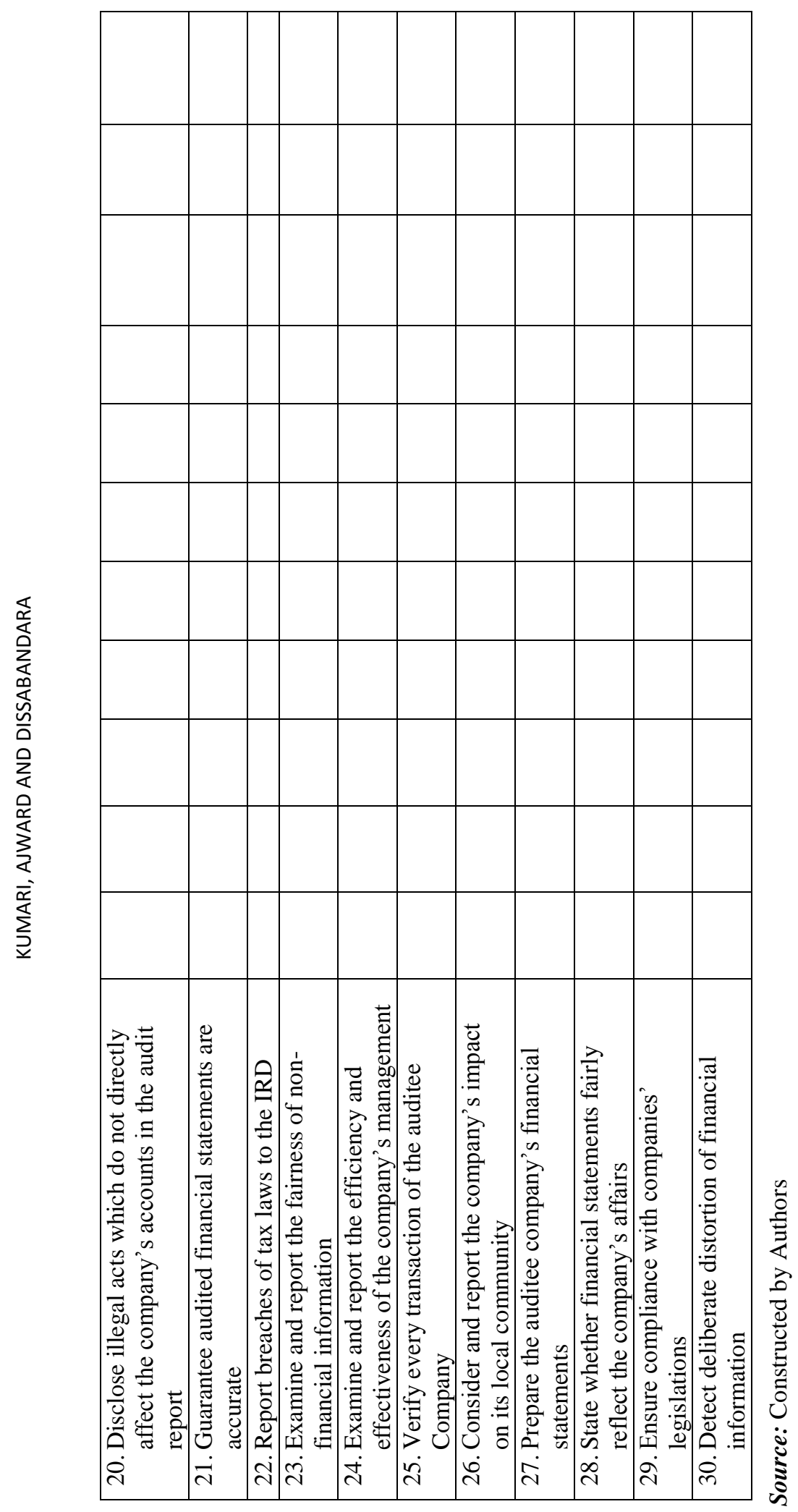

